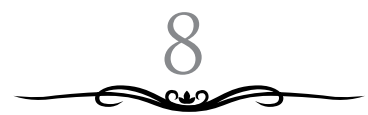

\title{
PENGELOLAAN PERPUSTAKAAN PERGURUAN TINGGI BERBASIS AKREDITASI
}

\author{
Aris Nurohman \\ IAIN Purwokerto, Jawa Tengah, Indonesia \\ arisnurohman@gmail.com
}

\begin{abstract}
Library accreditation is a procedure in order to evaluate all the activities of the organization of the library is measured based on the parameters specified quality standards. The standard is the benchmark measure of quality. Managing the college library-based accreditation means applying the concept of accreditation in the management of the library. There are nine components that need to be referenced accreditation based library management services, collaboration, collection, organizing library materials, human resources, building / space and infrastructure, budget, library management and collections care. Ninth aspect of this being used as a reference library management roadmap in order to realize the quality of the library.
\end{abstract}

Keywords: Libraries, Accreditation, Assessment, Management Library.

\begin{abstract}
Abstrak
Akreditasi perpustakaan adalah kegiatan dalam rangka mengevaluasi seluruh aktifitas penyelenggaraan perpustakaan diukur berdasarkan parameter standar kualitas tertentu. Standar adalah acuan ukuran kualitas. Mengelolaan perpustakaan perguruan tinggi berbasis akreditasi berarti menerapkan konsep
\end{abstract}


akreditasi dalam manajemen pengelolaan perpustakaan. Terdapat sembilan komponen yang perlu dijadikan acuan pengelolaan perpustakaan berbasis akreditasi layanan, kerjasama, koleksi, pengorganisasian bahan perpustakaan, sumber daya manusia, gedung/ruang dan sarana prasarana, anggaran, manajemen peprustakaan dan perawatan koleksi. Pengelolaan perpustakaan Kesembilan aspek ini menjadi acuan yang dijadikan sebagai roadmap pengelolaan perpustakaan dalam rangka mewujudkan perpustakaan yang kualitas .

Kata Kunci: Perpustakaan, Akreditasi, Penilaian, Manajemen Perpustakaan.

\section{A. Pendahuluan}

Beberapa tahun belakangan penyelenggaraan dan pengelolaan perpustakaan perguruan tinggi mulai difokuskan pada kesiapan akreditasi. Bukan sekedar akreditasi program studi yang ada dilingkungan perguruan terkait saja, melainkan akreditasi perpustakaan itu sendiri. Kemajuan ini patut dibanggakan, sebagai bentuk perhatian pemerintah terhadap peran strategis perpustakaan dalam mendukung tri dharma perguruan tinggi di Indonesia.

Dalam paradigma baru pengelolaan perguruan tinggi, bahwa untuk dapat memiliki kemampuan pengelolaan yang bermutu dan punya daya saing, maka harus memiliki sistem penjaminan mutu, yaitu rencana sistem yang memastikan bahwa apa yang telah direncanakan harus dapat dilaksanakan dan dicapai. ${ }^{1}$ Paradigma pengelolaan perguruan tinggi ini kiranya bisa diterapkan juga sebagai model pengelolaan perpustakaan.

Kenyataanya saat ini, dunia perpustakaan terus berhadapan dengan tuntutan kualitas jasa layanan yang diberikan. Kualitas jasa semakin berkembang bersanding dengan iklim persaingan

${ }^{1}$ Sugeng Listyo Prabowo. 2009. Implementasi Sistem Manajemen Mutu ISO 9001:2008. Malang: UIN Press. Hlm. 19-20. 
dalam rangka pemenuhan tuntutan kebutuhan. Pada akhirnya perpustakaan menjadi institusi yang harus selalu responsif dan adaptif terhadap perubahan dan kemajuan guna meningkatkan nilai tawar kualitas layanan. Fenomena ini juga pernah disinggung oleh Ida F Priyanto dalam pendapat yang mengatakan bahwa perpustakaan merupakan living organism-organisme yang hidup dan mengikuti perubahan yang terjadi dalam lingkungannya. ${ }^{2}$

Mendasarkan pada kenyataan tersebut maka pengelolaan perpustakaan secara profesional yang mengedepankan kualitas layanan dan akuntabilitasnya menjadi sangat penting. Oleh karena itu, dalam pengelolaan perpustakaannya harus sudah didukung dengan acuan standar kualitas tertentu yang harus dicapai. Dengan demikian pengelola perpustakaan memiliki landasan pengelolaan yang berorientasi pada kualitas layanan.

Terkait dengan akreditasi perpustakaan sebagai bagian dari sistem penilaian atau asesmen terhadap kinerja perpustakaan, kiranya relevan untuk dijadikan sebagai standar acuan pengelolaan. Sebab sistem penilaian melalui akreditasi ini pada dasarnya merupakan proses kendali mutu perpustakaan yang menjadi sistem kontrol dalam pengelolaan perpustakaan. Sistem kontrol ini akan memberikan umpan balik bagi internal pengelola perpustakaan melalui upaya pembenahan dan evaluasi.

Ruh dari pelaksanaan akreditasi secara tidak langsung dapat menumbuhkan kesadaran akan pentingnya pengelolaan organisasi, termasuk perpustakaan sebagai unit maupun pusat dalam sebuahinstitusiinduk. Kuncidarikesadaranakan pentingnya kualitas perpustakaan dan peran strategisnya mendukung upaya terwujudnya tri dharma perguruan tinggi adalah manajemen pengelolaan organsiasi dan manajemen pengelolaan perpustakaan. Oleh karena itu, dalam penulisan ini penulis sengaja akan mengangkat masalah tentang bagaimana menggagas tata kelola organisasi, dan lebih spesifik dalam pengelolaan perpustakaan di

${ }^{2}$ Ida F. Priyanto. Perpustakaan Akademik Dalam Bingkai Perguruan Tinggi Berkualitas. Makalah. Diakses melalui www.digilib.ugm.ac.id. Tanggal 10 Februari 2016. 
lingkungan perguruan tinggi yang sinergi untuk mencapai tujuan perpustakaan bermutu berbasis akreditasi perpustakaan.

\section{B. PEMBAHASAN}

\section{Memahami Akreditasi Perpustakaan}

Akreditasi merupakan suatu proses evaluasi dari pihak eksternal terhadap suatu institusi tertentu melalui pengkajian, pembuktian dan penilaian atau disebut dengan proses asesmen berdasarkan kriteria dan standar yang sudah dibuat sebagai acuan terhadap penjaminan, perbaikan dan kendali mutu. ${ }^{3}$ Dapat dikatakan bahwa akreditasi merupakan penilaian atau asesmen tentang sejauh mana tata kelola sumber daya perpustakaan yang benar-benar efektif dalam mencapai tujuan perpustakaan yang sebenarnya.

Memahami urgensi akreditasi bidang perpustakaan penulis pahami dari definisi perpustakaan yang tertuang dalam undangundang nomor 43 tahun 2007 tentang perpustakaan pasal 1 yang disebutkan bahwa perpustakaan adalah institusi pengelola karya tulis, karya cetak dan atau karya rekam secara profesional dengan sistem yang baku guna memenuhi kebutuhan pendidikan, penelitian, pelestarian, informasi dan rekreasi para pemustaka. Pasal ini menekankan tentang fungsi perpustakaan sebenarnya.

Dalam kondisi nyata, definisi perpustakaan sebagaimana undang-undangterjabarkan dalamseluruh prosespenyelenggaraan perpustakaan, mulai dari gedung dan sarana prasarana, sumber daya manusia, manajemen, anggaran, pengelolaan bahan perpustakaan, koleksi, jasa layanan, preservasi, sampai kerjasama. Perpustakaan tidak bisa diartikan secara sempit sebagai tempat dan layanan koleksi, melainkan organisasi yang terus akan hidup, dan dikelola secara sinergis baik oleh pengelola, jajaran pimpin,

${ }^{3}$ Adwityani S. Subagio, 2012. Persiapan Akreditasi Bidang Perpustakaan di Perguruan Tinggi. Makalah disampaikan pada workshop nasional Persiapan Akreditasi bidang Perpustakaan di Perguruan Tinggi di Jakarta tanggal 12 Juli 2012, hlm. 1. 
segenap stake holders dan pemerintah, maupun sinergis antara tujuan visi-misi dan program kerja.

Akreditasi perpustakaan yang dalam hal ini melalui proses asesmen, dilakukan untuk mengukur ketercapaian perpustakaan dalam menjalankan tujuan dan fungsinya sesuai amanat undang-undang perpustakaan. Implementasi akreditasi ini kemudian dijadikan dasar pertimbangan tentang sistem manajemen pengelolaan perpustakaan. Sebagaimana dikatakan bahwa akreditasi perpustakaan dapat meningkatkan kepercayaan pemustaka terhadap kinerja perpustakaan serta menjamin konsistensi kualitas kegiatan perpustakaan. Sedangkan manfaat dari akreditasi perpustakaan adalah meningkatkan motivasi semua unsur yang terlibat dalam pengelolaan perpustakaan untuk meningkatkan kinerjanya. ${ }^{4}$

Sejalan dengan hal ini, dikatakan pula oleh Mustofa, bahwa manfaat akreditasi diantaranya:

1. Membangun kualitas lembaga perpustakaan;

2. Menentukan derajat pemenuhan standar pada suatu perpustakaan;

3. Memotivasi pengelola perpustakaan untuk membangun perpustakaan ke jenjang yang labih baik dan profesional;

4. Mengangkat citra perpustakaan;

5. Meningkatkan pengakuan pasar atau masyarakat terhadap kinerja perpustakaan;

6. Memberikan sarana perpustakaan untuk memperjuangkan anggaran ${ }^{5}$.

Pernyataan dari pendapat di atas tampak sekali adanya relevansi antara pengaruh akreditasi terhadap kualitas

${ }^{4}$ Ikhwan. Pentingnya Perpustakaan di Perguruan Tinggi. Makalah diakses melalui http://perpustakaan.unrama.ac.id tanggal 12 September 2016

5 Pendapat Musthofa dalam Komarudin. Akreditasi Perpustakaan Perguruan Tinggi: Pengalaman Perpustakaan STAIN Kediri. Jurnal Pustakaloka. Volume 8 nomor 1 (2016). Hlm. 18. 
perpustakaan. Secara otomatis tentunya aspek-aspek dalam akreditasi berhubungan langsung dengan kualitas perpustakaan.

Akreditasi prinsipnya adalah sebuah proses evaluasi dari pihak luar. Mengutip O’brien (2010) bahwa akreditasi adalah proses jaminan mutu dikendalikan oleh standar, kebijakan dan prosedur. Ada tiga komponen dalam akreditas yaitu standar sebagai parameter nilai, kebijakan sebagai acuan pelaksanaan penilaian (asesmen) dan prosedur adalah proses penilaian.

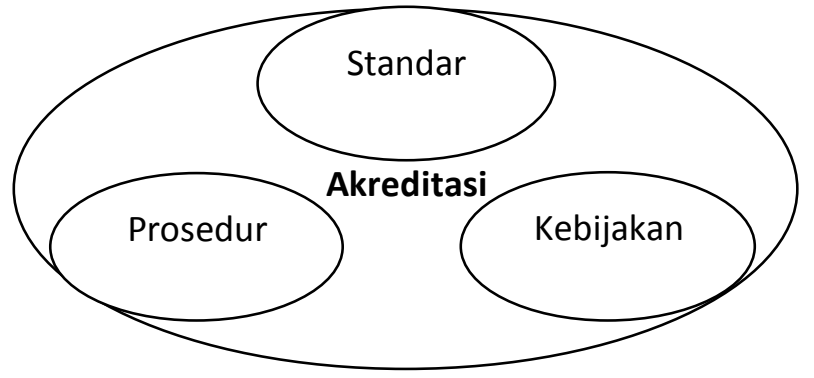

Gambar 1. Komponen Akreditasi (Sumber: O’brien, Karen L. (2010)

Pada awalnya, ketiga komponen tersebut yaitu standar, kebijakan dan prosedur adalah rangkaian komponen dalam pelaksanaan akreditasi perpustakaan. Setiap institusi yang akan mengajukan akreditasi biasanya akan mempelajari ketiga komponen tersebut. Di sisi lain, peta konsep akreditasi tersebut juga bisa diadopsi menjadi peta konsep manajemen pengelolaan perpustakaan dengan beberapa ubahan pola dan cara pandang dalam memaknai ruang lingkup dan penjabarannya.

Akreditasi adalah prosedur dalam rangka memberikan apresiasi dan pengakuan dari lembaga akreditasi terhadap sebuah organisasi secara formal sesuai dengan standar dan kelayakan tertentu kemudian dituangkan dalam kualifikasi tertentu yang mencerminkan kualitasnya. Mengingat akreditasi merupakan cara atau alat ukur kualitas, maka penerapannya dalam pengelolaan perpustakaan menjadikan standar akreditasi itu sendiri adalah sistem kendali mutu perpustakaan atau bisa disebut sistem manajemen mutu akreditasi (SMM-A). 
Dalam hal ini mutu atau kualifikasi akreditasi bukanlah tujuan pokok penyelenggaraan perpustakaan, melainkan bagaimana mengelola perpustakaan yang memenuhi standar manajemenmutuakreditasi.Artinya, setiappengelolaperpustakaan tidak terfokus pada capaian nilai akreditasi melainkan fokus pada bagaimana merencanakan, menata, melakukan dan mengevaluasi perpustakaan sesuai dengan standar yang berlaku.

\section{Implementasi Sistem Manajemen Mutu Akreditasi - SNP}

Standar kualitas perpustakaan dijadikan acuan dalam setiap pengukuran kualitas perpustakaan. Sedangkan akreditasi adalah salah satu cara memantau implementasi standar tersebut. ${ }^{6}$ Standar adalah ukuran tertentu yang digunakan sebagai dasar patokan, sebagai ukurab nilai maupun ukuran baku. ${ }^{7}$ Setidaknya ada dua standar nasional untuk perpustakaan, yaitu yang dibuat Badan Akreditasi Nasional Perguruan Tinggi atau disingkat BANPT dan yang dibuat Perpustakaan Nasional Republik Indonesia. Dalam hal ini akan difokuskan pada satu standar yaitu yang dibuat oleh perpustakaan nasional atau disebut sebagai standar nasional perpustakaan (SNI).

Standar nasional perpustakaan merupakan acuan dalam penyelenggaraan Perpustakaan Perguruan Tinggi, termasuk Perguruan Tinggi di dibawah naungan Kementerian Agama. Sebagaimana disebutkan dalam ruang lingkup SNP 010: 2011, standar perpustakaan ini menetapkan pengelolaan perpustakaan perguruan tinggi yang mampu memfasilitasi proses pembelajaran serta berperan dalam meningkatkan iklim akademik.

Sebagai acuan, standar tidak memberikan gambaran konkrit tentang kualifikasi perpustakaan secara riil. Namun standar memberikan rambu-rambu atau garis-garis besar capaian penyelenggaraan pengelolaan perpustakaan. Oleh karena itu, jika

${ }^{6}$ Paulus Suparmo. Mengagas Kualitas Perpustakaan Perguruan Tinggi. Makalah disampaikan pada woskhop Akreditasi Perpustakaan di STAIN Purwokerto. Purwokerto,13 Oktober 2012.

7 Tim Penyusun. 2007. Kamus Besar Bahasa Indonesia. Jakarta: Balai Pustaka. Hlm. 1089. 
standar perpustakaan ini dijadikan sebagai pedoman pengelolaan perpustakaan, maka perlu memahami secara rinci. Standar nasional perpustakaan juga hanya mengukur aspek pokok yang tidak menyinggung aspek pengaruh dan akibat.

Berbeda dengan instrumen akreditasi yang mengukur berbagai aspek terkait seluruh rangkaian pengelolaan mulai dari kelengkapan, ketersediaan, pendukung, proses, capaian, bahkan dampak/ pengaruh yang ditimbulkan. Itu sebabnya ada sedikit perbedaan ketika melihat dan memahami standar dengan ketika melihat dan memahami instrument akreditasi.

Artinya, implementasi dari sistem manajemen mutu akreditasi adalah dengan memahami ruang lingkup aspek dalam akreditasi dan mengejawantahkannya melalui aksi kongkrit pengelolaan perpustakaaan. Berikut gambaran dari standar nasional perpustakaan dan instrumen dalam akreditasi perpustakaan:

Tabel 1. Instrumen Akreditasi Perpustakaan

\begin{tabular}{clcl}
\hline No & \multicolumn{1}{c}{ SNP } & No & \multicolumn{1}{c}{ Instrumen Akreditasi } \\
\hline 1 & Koleksi & 1 & Layanan \\
\hline 2 & Sarana dan Prasarana & 2 & Kerjasama \\
\hline 3 & Layanan & 3 & Koleksi \\
\hline 4 & Tenaga (SDM) & 4 & $\begin{array}{l}\text { Pengorganisasian Bahan } \\
\text { Perpustakaan }\end{array}$ \\
\hline 5 & $\begin{array}{l}\text { Penyelenggaraan dan } \\
\text { Pendirian }\end{array}$ & 5 & SDM \\
\hline 6 & Pengelolaan & 6 & Gedung/ruang, sarana prasarana \\
\hline 7 & $\begin{array}{l}\text { Teknologi Informasi \& } \\
\text { Komunikasi }\end{array}$ & 7 & Anggaran \\
\hline & & 8 & Manajemen Perpustakaan \\
\hline & 9 & Perawatan Koleksi Perpustakaan \\
\hline
\end{tabular}

Sumber: SNP 010: 2011 dan Instrumen Akreditasi Perpustakaan.

\section{a. Aspek Layanan}

Standar layanan terdiri dari aspek-aspek acuan yang menjamin kualitas layanan perpustakaan. Ada berapa hal yang berkaitan dengan ukuran kualitas layanan, diantaranya :

1. Waktu untuk layanan, 
Waktu layanan adalah seberapa waktu yang diberikan kepada pemustaka untuk mennikmati setiap layanan yang tersedia di perpustakaan. Lama waktu layanan ditentukan oleh jam buka-tutup perpustakaan. Sering terjadi, pengelola perpustakaan membedakan antara antara jam kerja staf dan kerja layanan. Jam kerja staf dihitung mulai jam datang dan pulang dikurangi jam istirahat. Sedangkan jam layanan adalah jam yang dialokasikan untuk memberikan layanan kepada pemustaka. Selisih waktu jam kerja dan layanan biasanya antara 30 sampai 60 menit perhari dengan asumsi, buka layanan 15-30 menit setelah datang di perpustakaan dan tutup layanan 15-30 menit sebelum pulang kerja.

Di lingkungan PTKIN, ketentuan baku tentang jam kerja minimal ditetapkan sebanyak 37,5 jam perminggu, dihitung berdasarkan selisih jam masuk dan pulang dikurangi jam istirahat. Jika kemudian institusi memberlakukan lima hari kerja, maka $37,5 / 5=7,5$ jam/hari. Kemudian diatur jam masuk kantor yaitu pukul 07.30 dan pulang pukul 16.00 untuk hari senin sampai kamis, pulang pukul 16.30 untuk hari jum'at, dikurangi jam istirahat 1 jam (pukul 12.00-13.00) untuk hari senin- jumat dan 1,5 jam (11.30 - 13.00) untuk hari jum'at). Jika kemudian terdapat perbedaan antara jam masuk kerja dan jam buka layanan, maka jam efektif layanan adalah $((37,5-(1 \times 5))=32,5 \mathrm{jam} / \mathrm{minggu}=$ 6,5 jam/hari. Belum lagi ada jeda waktu tutup di tengah hari untuk istirahat. Tentu jumlah lama waktu layanan ini sangat tidak ideal dalam mewujudkan fungsi dan tujuan perpustakaan.

Ditingkat perguruan tinggi, mobilitas mahasiwa dan dosen cukup tinggi. Belum lagi jadwal kuliah yang terkadang menghendaki untuk sampai malam hari atau diluar jam kerja karyawan. Oleh karena itu, agar sangat diperhatikan oleh segenap pengelola perpustakaan dan pimpinan perguruan tinggi, tentang lama waktu buka layanan perpustakaan.

Kualitas layanan berkualitas sedidaknya memiliki jam layan lebih dari 48 jam perminggu. Jika demikian, maka waktu layanan kepada pemustaka jelas sangat jauh dari standar yang 
seharusnya. Kekurangan jam layanan akan berimbas pada keterbatasan akses informasi dan juga nilai kepuasan pemustaka. Oleh karena itu, perlu untuk menata ulang layanan perpustakaan dari sisi optimalisasi jam layanan pemustaka. Ada dua cara mengoptimalkan jam layanan yaitu pola shift di jam istirahat, optimalisasi kinerja staf dan pola lembur diluar jam kerja.

Pola shift istirahat staf sangat potensial mengurangi kekurangan jam layanan. Peprustakaan tidak perlu tutup layanan bagi pemustaka, karena ada pergantian jam istirahat staf. Penerapan pola shift jam istirahat ini akan menambah lama jam layanan setidaknya 5 jam/ minggu.

Optimalisasi jam kerja staf dilakukan untuk meminimalisir waktu tidak terpakai di jam kerja staf. Perlu kiranya dilakukan peninjaun ulang tentang beban kerja, deskripsi kerja dan evaluasi kinerja staf. Jangan sampai staf terlalu berat dibebani pekerjaan, dan jangan pula staf dimanja oleh kelonggaran jam kerja. Dengan optimalisai jam kerja staf, maka setidaknya akan menghemat waktu 2,5 jam per minggu dengan asumsi memaksimalkan jam buka dan meminimalisir jam tutupnya. Jika dijumlahkan maka sudah ada penghematan waktu sebanyak 7,5 jam per-minggu untuk menambah jam layanan. Sisanya bisa memberikan tambahan jam lembur di hari aktif, misalnya sampai pukul 19.30 dan penggunaan hari sabtu-minggu untuk buka layanan dengan perhitungan lembur di luar jam kerja. Pola ini dilakukan untuk memenuhi kebutuhan layanan kepada pemustaka. Semakin banyak waktu yang tersedia untuk layanan, semakin besar kepuasan pemustaka.

2. Sistem layanan,

Perkembangan teknologi dan informasi yang semakin pesat sudah direspon hampir oleh sebagian besar pengelola perpustakaan perguruan tinggi. Teknologi menjadi kebutuhan penting untuk layanan perpustakaan. Banyaknya website perpustakaan berisi informasi tentang kepustakaan, dan layanan informasi maya sudah mengalami booming. Yang paling baru adalah sedang maraknya pengembangan website repository berbasis online. 
Meski demikian, masih mensisakan sedikit persoalan terkait dengan implementasilayanan berbasis website atau internet. Beberapa pertimbangan diantaranya untuk keamanan data, belum ada kesiapan dari sisi sumber daya, dan biaya maintenance menyebabkan aplikais layanan berbasis online masih belum menyeluruh. Fenomena sekarang baru menunjukan fase aplikasi sistem hibrida, yaitu layanan separuh dilayankan melalui jaringan internet (contoh repository, informasi katalog), dan separuh lagi masih intranet offline dengan face-to-face petugas, terutama peminjaman koleksi.

Kedepan, kiranya sangat perlu inovasi tentang aplikasi internet sebagai alat pendukung layanan perpustakaan secara menyeluruh. Inovasi semacam ini entah cepat atau lambat akan menjadi tren tuntutan kebutuhan, tanpa menghilangkan system lama yang berbasis manual. Pengelolaan perpustakaan harus memiliki strategi perencanaan yang matang untuk tujuan ini. Karena implementasi rencana ini terkait dengan sumber daya baik SDM, dana dan dukungan dari semua pihak. Efek lain dari penerapan teknologi informasi dalam mendukung layanan adalah peningkatan kualitas sekaligus kuantitas pemustaka sebagai konsumen informasi perpustakaan.

\section{Macam layanan}

Macam-macam layanan yang diberikan sesuai kebutuhan dari berbagai tipe pemustaka sangat dibutuhkan. Pelayanan yang responsive terhadapkebutuhan pemustaka tentu sangat dibutuhkan sebab harapan pemustaka setiap datang keperpustakaan adalah menemukan apa yang dicari dan menemukan apa yang baru. Untuk memahami kebutuhan pemustaka secara obyektif akan lebih tepat jika dilakukan survei kebutuhan secara rutin. Dari survei tersebut nantinya akan ditemukan keutuhan apa yang mereka inginkan. Selanjutnya ditindak lanjuti dengan menyediakan kebutuhan tersebut. Selama belum adanya survey kebutuhan, maka pengelola bisa menggunakan pedoman standar macam-macam layanan yang ada di perpustakaan perguruan tinggi. 
Layanan kepada pemustaka tidak harus bersifat jasa layanan informasi langsung seperti layanan bimbingan rujukan, bimbingan foto kopi dan semacamnya. Perlu dipertimbangkan penyediaan layanan yang sifatnya membantu menemukan informasi kepada pemustaka. Jenis layanan ini telah mulai menjadi fokus pemerhati perpustakaan dan kalangan professional pustakawan, tentang layanan pendidikan pemustaka dan layanan pendidikan literasi informasi. Kebutuhan terhadap layanan ini sudah dianggap cukup penting akibat dari perkembangan teknologi informasi dan membanjirnya informasi (information booming). Jenis layanan ini ada yang dilakukan atas inisiatif pengelola perpustakaan dan profesioanal pustakawan dengan menawarkan program pendidikan non SKS atau kerkadang atas permintaan pemustaka itu sendiri. Untuk mempersiapkannya maka pustakawan harus diberi pembekalan tentang literasi atau terkadang mereka sudah memiliki wawasan tentang itu di bangku kuliah ilmu perpustakaan sebelumnya.

4. Dampak dari layanan

Layanan yang lengkap, berkualitas, dan prima tentu memiliki dampak positif. Kepuasan pemustaka salah satunya menjadi ukuran normatif kualitas perpustakaan efek dari layanan prima. Semakin tinggi nilai kualitas perpustakan akan semakin meningkatkan ketertarikan pemustaka untuk mendapatkan layanan. Semakin tinggi pula ketergantungan mereka kepada perpustakaan. Dari sisi kualitas dan kuantitas pemustaka saling bertautan. Artinya, jika kualitas perpustakaan sudah memadai dan tercapai, maka kualitas pemustaka semakin meningkat seiring dengan itu, kuantitas pemustaka juga akan mengikutinya. Hal ini yang perlu disoroti oleh setiap pengelola perpustakaan agar jangan mengabaikan kualitas layanan.

\section{Promosi layanan}

Promosi layanan merupakan salah satu strategi untuk lebih mendayagunakan perpustakaan bagi masyarakat pemustaka. Selain dalam konsep sederhananya adalah menyebarkan informasi terkini, ada juga konsep promosi melalui berbagai saluran media. 
Tujuannya adalah agar masyarakat lebih mengenal perpustakaan. Masyarakat cepat memahami perubahan dan perkembangan perpustakaan, serta menjadilebih tanggap terhadap perkembangan teknologi dan informasi yang berkembang di perpustakaan. Selain dari manfaat ini, ada manfaat lain yang tidak langsung yaitu melalui promosi akan semakin terukur tingkat perkembangan yang ada di perpustakaan, dan menjadi dasar pemustaka memberikan kritikan sekaligus otokritik internal pengelola perpustakaan.

6. Pendukung layanan

Perpustakaan harus didukung dengan aplikasi teknlogi informasi terbarukan yang sangat membantu kegiatan layanan kepada pemustaka. Jika perkembangan sebelumnya baru sebatas katalog offline, maka perkembangan selanjutnya adalah kemudahan akses secara online. Jika sebelumnya layanan masih berbasis face-to-face, antar muka dengan petugas, maka layanan selanjutnya adalah melalui jaringan internet. Jika layanan sebelumnya berbasis printed book-journal saja, maka layanan selanjutnya adalah memperkaya dengan ketersediaan e-book dan ejournal yang dilayankan secara online.

Secara keseluruhan yang perlu diperhatikan dalam implementasi manajemen perpustakaan berbasi akreditasi pada aspek layanan dapat dirangkum dalam tabel sebagai :

Tabel 2. Kualifikasi Standar Akreditasi Aspek Layanan

\begin{tabular}{lccc}
\hline Aspek & \multicolumn{3}{c}{ KUALIFIKASI KUALITAS } \\
\cline { 2 - 4 } & CUKUP $(\mathrm{C})$ & BAIK (B) & UNGGUL (A) \\
\hline Jam layanan / hari & $\leq 8 \mathrm{jam}$ & $\leq 10 \mathrm{jam}$ & $>10 \mathrm{jam}$ \\
\hline Jam layanan / minggu & $\leq 41 \mathrm{jam}$ & $\leq 48 \mathrm{jam}$ & $>48 \mathrm{jam}$ \\
\hline System peminjaman & Kartu & Otomatis & $\begin{array}{c}\text { Kartu }+ \\
\text { otomatis }\end{array}$ \\
\hline Jumlah Pemustaka Mhs & $\leq 60 \%$ & $\leq 80 \%$ & $>80 \%$ \\
\hline $\begin{array}{l}\text { Jumlah Pemustaka dosen } \\
\text { dan Karyawan }\end{array}$ & $\leq 60 \%$ & $\leq 80 \%$ & $>80 \%$ \\
\hline $\begin{array}{l}\text { Rata-Rata buku dipinjam/ } \\
\text { bln }\end{array}$ & $\leq 5.500 \mathrm{jdl}$ & $\leq 6.000 \mathrm{jdl}$ & $>6.000 \mathrm{jdl}$ \\
\hline $\begin{array}{l}\text { Jenis promosi dan } \\
\text { penyebaran informasi }\end{array}$ & $\leq 5$ jenis & $\leq 8$ jenis & $>8$ jenis
\end{tabular}




\begin{tabular}{lccc}
\hline $\begin{array}{l}\text { Promosi perpustakaan/ } \\
\text { thn }\end{array}$ & $\leq 5 \mathrm{kali}$ & $\leq 8 \mathrm{kali}$ & $>8 \mathrm{kali}$ \\
\hline Layanan berbasis TIK & Intranet & Internet & $\begin{array}{c}\text { Intranet }+ \\
\text { Internet }\end{array}$ \\
\hline Kegiatan literasi /tahun & $\leq 2 \mathrm{kali}$ & $\leq 3 \mathrm{kali}$ & $>3 \mathrm{kali}$ \\
\hline Otomasi perpustakaan & OPAC & OPAC, sirkulasi & $\begin{array}{c}\text { OPAC, } \\
\text { sirkulasi, } \\
\text { keanggotaan }\end{array}$ \\
\hline Layanan & Baca, & $\begin{array}{c}\text { Baca, sirkulasi, } \\
\text { penelusuran, } \\
\text { sirkulasi, } \\
\text { penelusuran } \\
\text { pemakai }\end{array}$ & $\begin{array}{c}\text { Bacal sirkulasi, } \\
\text { penelusuran, } \\
\text { bimbingan } \\
\text { pemakai, foto } \\
\text { copy }\end{array}$ \\
\hline
\end{tabular}

Sumber: Akreditasi Perpustakaan Perguruan Tinggi. 2011.

\section{b. Aspek Kerjasama}

Sering terjadi dalam sebuah pengelolaan perpustakaan, struktur organisasi, maupun kebijakan organisasi tidak dipahami. Akibatnya, banyak rencana kegiatan dan usulan anggaran yang kurang mendapat dukungan dari pimpinan dan berbagai pihak. Salah satunya ketika perencanaan pengadaan koleksi, pengelola perpustakaan mencukupkan kerja seleksi kepada pustakawan bagian pengolahan dan tidak melibatkan unsur dekanat, jurusan atau prodi. Akibatnya, koleksi terkadang tidak sesuai harapan dan kebutuhan pemustaka.

Di sisi lain, keluhan pemustaka seputar kurangnya koleksi atau koleksi yang dibutuhkan tidak tersedia di perpustakaannya institusinya sendiri sudah sering terjadi. Tidak menutup kemungkinan koleksi yang dicarinya ini rupanya tersedia di perpustakaan perguruan tinggi lain. Namun karena belum adanya jalinan kerjasama silang layan antar perpustakaan, maka keterbatasan kepemilikan koleksi ini tidak ada solusinya.

Berdasarkan kedua masalah ini seharusnya menggugah kepekaan profesionalisme pengelola perpustakaan untuk melahirkan ide dan solusi yang salah satunya melalui jalinan kerjasam baik kerjasama internal maupun eksternal. 
Kerjasama internal adalah kerjasama dalam lingkup pengelolaan organisasi yang bersinergi dengan stake holders internal seperti jajaran pimpinan perguruan tinggi, dekanat, jurusan, program studi, terkait anggaran, kebijakan, dan operasional. Sementara kerjasama eksternal adalah kerjasama dengan instansi diluar institusinya seperti dengan perpustakaan perguruan tinggi lain, perpustakaan instansi lain dan sebagainya. Kerjasama ini bertujuan sebagai wadah saling tukar informasi, jasa layanan silang dan sebagainya. Kedua kerjasama ini tidak bisa diabaikan satu sama lainnya.

Secara keseluruhan yang perlu diperhatikan dalam implementasi manajemen perpustakaan berbasi akreditasi pada aspek kerjasama dapat dirangkum tabel sebagai berikut:

Tabel 3. Kualifikasi Standar Akreditasi Aspek Kerjasama

\begin{tabular}{cccc}
\hline \multirow{2}{*}{ Aspek } & \multicolumn{3}{c}{ KUALIFIKASI KUALITAS } \\
\cline { 2 - 4 } & CUKUP (C) & BAIK (B) & UNGGUL (A) \\
\hline $\begin{array}{c}\text { Jumlah kerjasama internal } \\
\text { PT/ thn }\end{array}$ & 2 kali & 3 kali & $>3$ kali \\
\hline $\begin{array}{c}\text { Jumlah kerjasama } \\
\text { eksternal/thn }\end{array}$ & 2 kali & 3 kali & $>3$ kali \\
\hline $\begin{array}{c}\text { Jumlah koleksi buku } \\
\text { tercetak }\end{array}$ & $\leq 5.000 \mathrm{jdl}$ & $\leq 10.000 \mathrm{jdl}$ & $>10.000 \mathrm{jdl}$ \\
\hline
\end{tabular}

Sumber: Akreditasi Perpustakaan Perguruan Tinggi. 2011.

\section{c. Aspek Koleksi}

Dalam akreditasi perpustakaan, tiap prodi harus sudah memiliki koleksi referensi lebih dari 500 judul. Ukuran ini jelas harus dipakai sebagai ukuran standar untuk memenuhi syarat kualitas. Jika dalam sebuah perguruan tinggi terdapat 20 program studi, maka total koleksi referensi perpustakaan sudah sebanyak 10.000 judul, belum ditambah dengan koleksi penunjang, jurnal, laporan penelitian dan lokal kontent lainnya.

Perhatian tentang local content berimbas pada kebutuhan wadah fisik dan wadah elektronik. Wadah fisik adalah tempat dimana fisik dokumen koleksi tersimpan. Sedangkan wadah elektronik adalah sarana dimana bentuk elektronik atau digital 
dari file dokumen koleksi tersimpan, baik dalam sebuah website untuk penyimpanan format digital.

Merealisasikan kebutuhan-kebutuhan ini berkaitan erat dengan panganggaran. Penganggaran yang efektif dan efisien adalah penganggaran yang proporsional yang mempertimbangkan kebutuhan masyarakat pemustaka. Proporsi pengadaan perlu lebih besar dari 16\% pertahun dengan distribusi alokasi sebagaimana berikut:

1. Buku refernsi utama minimal $80 \%$

2. Buku Referensi penunjang 20\% (kamus, ensiklopedi, statistic, laporan, manual, dsb)

3. Langganan jurnal ilmiah tercetak minimal 3 judul/ prodi

4. Langganan jurnal ilmiah online minimal 3 judul/prodi

5. Langganan surat kabar minimal 4 judul

6. Memperkirakan kenaikan harga (mengikuti fluktuatif harga buku)

7. Pembuatan website

Selain dari kegiatan yang berhubungan dengan pengadaan, juga harus disediakan alokasi dana khusus untuk kebutuhan kegiatan diluar pengadaan, sebagai contoh dana preservasi, stok opname koleksi dan juga dana untuk pelaksanaan survei kebutuhan koleksi. Untuk meningkatkan daya guna koleksi, sebaiknya kegiatan tersebut rutin dilakukan, minimal satu tahun sekali. Mengingat kerusakan koleksi adalah fenomena yang lazim untuk sebuah buku koleksi. Semakin banyak koleksi yang ada, semakin tinggi resiko kerusakan dan semakin menambah beban pekerjaan preservasi. Jika diabaikan, maka akan semakin membebani tugas layanan dan tugas bagian pengolahan.

Demikian juga stokopname, kegiatan ini berkaitan dengan kegiatan untuk mengetahui status koleksi. Karena sering terjadi, data rekam jumlah koleksi terkadang tidak sesuai dengan keberadaanya di ruang koleksi. Ada yang karena dipinjam, diperbaiki, koleksi yang tinggi frekwensi sirkulasinya, sudah tidak terpakai lagi, koleksi hilang dan juga mengetahui judul yang belum 
tersedia. Hasil dari kegiatan stok opname adalah rekomendasi untuk pengembangan koleksi, pemilahan (weeding), maupun rencana pengadaan kembali.

Secara keseluruhan yang perlu diperhatikan dalam implementasi manajemen perpustakaan berbasi akreditasi pada aspek koleksi dapat dirangkum sebagai sebuah tabel berikut:

Tabel 4. Kualifikasi Standar Akreditasi Aspek Koleksi

\begin{tabular}{|c|c|c|c|}
\hline \multirow[t]{2}{*}{ Aspek } & \multicolumn{3}{|c|}{ KUALIFIKASI KUALITAS } \\
\hline & CUKUP (C) & BAIK (B) & UNGGUL (A) \\
\hline Jumlah koleksi buku tercetak & $\leq 5.000 \mathrm{jdl}$ & $\leq 10.000 \mathrm{jdl}$ & $>10.000 \mathrm{jdl}$ \\
\hline $\begin{array}{l}\text { Prosentasi koleksi penunjang } \\
\text { kurikulum dari total koleksi }\end{array}$ & $\leq 50 \%$ & $\leq 80 \%$ & $>80 \%$ \\
\hline Jumlah koleksi referensi & $\leq 400$ & $\leq 500 \%$ & $>500 \%$ \\
\hline Langganan surat kabar & $\leq 3 \mathrm{jdl}$ & $\leq 4 \mathrm{jdl}$ & $>4 \mathrm{jdl}$ \\
\hline Langganan majalah & $\leq 3 \mathrm{jdl}$ & $\leq 4 \mathrm{jdl}$ & $>4 \mathrm{jdl}$ \\
\hline Langganan jurnal ilmiah/prodi & $\leq 2 \mathrm{jdl}$ & $\leq 3 \mathrm{jdl}$ & $>3 \mathrm{jdl}$ \\
\hline Langganan e-journal & $\leq 2 \mathrm{jdl}$ & $\leq 3 \mathrm{jdl}$ & $>3 \mathrm{jdl}$ \\
\hline $\begin{array}{l}\text { Jumlah koleksi local content } \\
\text { total } 3 \text { thn }\end{array}$ & $\leq 1.500 \mathrm{jdl}$ & $\leq 2.000 \mathrm{jdl}$ & $>2.000 \mathrm{jdl}$ \\
\hline $\begin{array}{l}\text { Prosentase penambahan } \\
\text { koleksi/thn }\end{array}$ & $\leq 10 \%$ & $\leq 16 \%$ & $>16 \%$ \\
\hline Kegiatan stok opname & 3 tahun & 2 tahun & 1 tahun \\
\hline Kegiatan penyiangan & 3 tahun & 2 tahun & 1 tahun \\
\hline $\begin{array}{l}\text { Kegiatan rutin survey } \\
\text { kebutuhan }\end{array}$ & Wawancara & Kuisoner & $\begin{array}{l}\text { Wawancara + } \\
\text { kuisioner }\end{array}$ \\
\hline Jumlah e-resources & $\leq 1.500 \mathrm{jdl}$ & $\leq 2.000 \mathrm{jdl}$ & $>2.000 \mathrm{jdl}$ \\
\hline Website perpustakaan & ada & $\begin{array}{l}\text { Ada konten } \\
\text { kurang } \\
\text { lengkap }\end{array}$ & $\begin{array}{l}\text { Ada konten } \\
\text { lengkap }\end{array}$ \\
\hline
\end{tabular}

Sumber: Akreditasi Perguruan Tinggi. 2011.

\section{d. Aspek Pengorganisasian Bahan Perpustakaan}

Pengorganisasian bahan perpustakaan adalah kegiatan yang ruang lingkupnya seputar bahan perpustakaan (prossesing) mulai dari rencana pengadaan sampai siap untuk dilayankan. Kegiatannya mencakup :

1. Seleksi 
Seleksi yang tepat sasaran, sesuai kebutuhan dan mutakhir, masuk dalam daftar usulan pengadaan. Seleksi yang baik harus menggunakan sarana bantu seleksi yang lengkap dan mutakhir. Perlu diusahakan untuk setiap perpustakaan memiliki dokumen tentang informasi yang lengkap dan mutakhir. Karena kebutuhan ini menyangkut hasil pengadaan bahan perpustakaan yang sesuai kebutuhan, tepat guna dan tepat sasaran. Ada banyak alat seleksi, mulai dari usulan pemustaka (Dosen, mahasiswa), timbangan buku, bibliografi, katalog penerbit, anotasi, kumpulan abstrak dan resensi dan sebagainya.

2. Inventarisasi

Inventarisasi merupakan salah satu kegiatan yang wajib dilakukan setelah buku diterima. Jangan sampai pengelola perpustakaan mengabaikan inventarisasi. Karena terkait nomor induk buku masuk dan buku yang ada/ dimiliki perpustakaan itu sendiri.

3. Katalogisasi dan klasifikasi

Kegiatan katalogisasi dan klasifikasi merupakan kegiatan yang sangat fundamental dalam pengolahan buku. Dalam hal ini jika terdapat beberapa sistem klasifikasi, sebaiknya pengelola perpustakaan harus mampu memutuskan sistem yang akan dipakai dan konsisten terhadap keputusannya. Jangan sampai ada ketidak konsistenan sistem klasifikasi karena mempengaruhi penelusuran koleksi, dan mempengaruhi kepuasan pemustaka.

\section{Proses finising}

Proses finising merupakan kegiatan akhir menjelang bahan perpustakaan dilayankan kepada pemustaka. Proses ini harus dilakukan secara prosedural sehingga langkah kerja staf akan terarah dan dapat terkontrol sehingga hasilnya juga lebih baik.

Secara keseluruhan yang perlu diperhatikan dalam implementasi manajemen perpustakaan berbasi akreditasi pada aspek pengorganisasian bahan perpustakaan dapat dirangkum tabel berikut: 
Tabel 5. Kualifikasi Standar Akreditasi Aspek Pengorganisasian Bahan Perpustakaan

\begin{tabular}{cccc}
\hline \multirow{2}{*}{ Aspek } & \multicolumn{3}{c}{ KUALIFIKASI KUALITAS } \\
\cline { 2 - 4 } & CUKUP (C) & BAIK (B) & UNGGUL (A) \\
\hline Jumlah alat seleksi & $\leq 5$ jenis & $\leq 7$ jenis & $>7$ jenis \\
\hline $\begin{array}{c}\text { Proses pengolahan } \\
\text { buku }\end{array}$ & $\begin{array}{c}\text { Katalogisasi } \\
\text { manual }\end{array}$ & $\begin{array}{c}\text { Katalogiasasi } \\
\text { otomatis }\end{array}$ & $\begin{array}{c}\text { Katalogisasi } \\
\text { manual+otomatis }\end{array}$ \\
\hline Kelengkapan buku & $\begin{array}{c}\text { Kartu buku, } \\
\text { kantong buku, } \\
\text { slip kembali, }\end{array}$ & Barcode/chip & $\begin{array}{c}\text { Kartu buku, } \\
\text { kantong buku, }\end{array}$ \\
& label buku & & $\begin{array}{c}\text { slip kembali, label } \\
\text { buku + Barcode } \\
\end{array}$ \\
& & & / chip \\
\hline
\end{tabular}

Sumber: Akreditasi Perpustakaan Perguruan Tinggi. 2011.

\section{e. Aspek Sumber Daya Manusia (SDM)}

Perhatian terhadap SDM perpustakaan sudah diatur dalam pasal 39 ayat 1 (satu) Peraturan Pemerintah nomor 24 tahun 2014 tentang pelaksanaan UU nomor 43 tahun 2007 tentang perpustakaan yang menyebutkan bahwa Perpustakaan dipimpin oleh seorang pustakawan, kecuali memang dalam sebuah institusi belum ada yang memenuhi syarat untuk jabatan tersebut.

Selain kepemimpinan perpustakaan, pembinaan karir pustakawan juga harus diperhatikan. Fungsional pustakawan adalah tenaga professional yang memiliki tuntutan angka kredit, yang didalamnya mencakup kinerja kepustakawanan dan juga tuntutan pengembangan profesi dalam bentuk melakukan penelitian, penulisan karya ilmiah. Oleh karena itu, kesempatan pengembangan karir harus dilakukan baik ditingkat pengelola (unit/pusat perpustakaan) maupun tingkat institusional perguruan tinggi lembaga induknya.

Selain pustakawan, di perpustakaan juga terdapat staf perpustakaan nonprofessional, yang membantu di beberapa bagian pekerjaan perpustakaan. Keberadaan mereka sangat membantu tugas pustakawan. Terutama di perpustakaan perguruan tinggi yang memiliki pelanggan pemustaka hampir tiap hari cukup padat. Analisis kebutuhan ideal staf dan keseluruhan SDM perpustakaan ini cukup penting. Selain menata aspek kualitas staf, juga dari sisi kuantitas staf. 
Beberapa komponen yang perlu diperhatikan dalam implementasi manajemen perpustakaan berbasi akreditasi pada aspek SDM dapat dirangkum dalam tabel berikut:

Tabel 6. Kualifikasi Standar Akreditasi Aspek SDM

\begin{tabular}{|c|c|c|c|}
\hline \multirow[t]{2}{*}{ Aspek } & \multicolumn{3}{|c|}{ KUALIFIKASI KUALITAS } \\
\hline & CUKUP (C) & BAIK (B) & UNGGUL (A) \\
\hline Status kepala perpustakaan & $\begin{array}{l}\text { Tetap non } \\
\text { fungsional }\end{array}$ & $\begin{array}{l}\text { Fungsional } \\
\text { pendidik dan } \\
\text { kependidikan }\end{array}$ & $\begin{array}{l}\text { Fungsional } \\
\text { pustakawan }\end{array}$ \\
\hline $\begin{array}{l}\text { Jenjang peendidikan kepala } \\
\text { perpustakaan } 3 \text { thn terakhir }\end{array}$ & $\begin{array}{l}\text { S1-S3 non } \\
\text { perpustakaan }\end{array}$ & $\begin{array}{l}\text { S1-S3 non } \\
\text { perpustakaan } \\
\text { \& bersertifikat } \\
\text { perpustakaan }\end{array}$ & $\begin{array}{c}\text { S1-S3 } \\
\text { Perpustakaan }\end{array}$ \\
\hline $\begin{array}{l}\text { Jumlah diklat perpustakaan } \\
\text { oleh kepala perpustakaan }\end{array}$ & $\leq 4$ kali & $\leq 5$ kali & $>5$ kali \\
\hline $\begin{array}{c}\text { CPD kepala perpustakaan } 3 \\
\text { thn terakhir }\end{array}$ & $\leq 7$ kali & $\leq 10$ kali & $>10$ kali \\
\hline Jumlah staf perpustakaan & $\leq 10$ orang & $\leq 16$ orang & $>16$ orang \\
\hline $\begin{array}{l}\text { Jumlah staf berpendidikan } \\
\text { ilmu perpustakaan (D2-S3) }\end{array}$ & $\leq 5$ orang & $\leq 8$ orang & $>8$ orang \\
\hline $\begin{array}{l}\text { Jumlah fungsional } \\
\text { pustakawan }\end{array}$ & $\leq 1$ orang & $\leq 2$ orang & $>3$ orang \\
\hline $\begin{array}{c}\text { Jumlah diklat perpustakaan } \\
\text { oleh tenaga tetap } \\
\text { perpustakaan } 3 \text { thn }\end{array}$ & $\leq 6$ kali & $\leq 9$ kali & $>9$ kali \\
\hline $\begin{array}{l}\text { Jumlah rata-rata CPD } \\
\text { tenaga tetap perpustakaan }\end{array}$ & $\leq 8$ kali & $\leq 11$ kali & $>11$ kali \\
\hline $\begin{array}{c}\text { Jumlah tenaga } \\
\text { perpustakaan yang menjadi } \\
\text { anggota profesi }\end{array}$ & $\leq 6$ orang & $\leq 9$ orang & $>9$ orang \\
\hline
\end{tabular}

Sumber: Akreditasi Perpustakaan Perguruan Tinggi. 2011.

\section{f. Aspek Gedung/ Ruang, Sarana dan Prasarana}

Dalam penelitian yang pernah dilakukan oleh penulis sendiri di perpustakaan STAIN Purwokerto tahun 2009, diperoleh data bahwa perpustakaan dengan luas $1035 \mathrm{~m} 2$ dipaksakan untuk melayani masyarakat pemustaka sebanyak 3571 orang dianggap tidak memenuhi kebutuhan ideal. ${ }^{8}$ Contoh kasus ini menunjukan akan pentingnya aspek fisik gedung perpustakaan.

${ }^{8}$ Aris Nurohman. Gedung Perpustakaan: Fungsi dan Simbolismenya 
Demikian halnya penataan ruang dan beberapa peralatan pendukung, fasilitas sarana dan prasarana yang tersedia di perpustakaan harus memenuhi kualifikasi kebutuhan fasilitas secara ideal. Setidaknya ada beberapa pertimbangan dalam gedung, ruang, dan fasilitas maupun sarana dan prasarana perpustakaan sebagai berikut:

1. Gedung menempati lokasi strategis, mudah diakses

2. Proporsi alokasi fungsi ruang (ruang koleksi 45\%, ruang baca $25 \%$, ruang staf $20 \%$, ruang lain $10 \%$ )

3. Kebersihan ruang

4. Pencahayaan ruang

5. Sirkulasi dan pengatur suhu ruang

6. Keamanan didalam ruang dan gedung

7. Ketersediaan rak koleksi berbagai format dan jenisnya

8. Ketersediaan rak display

9. Ketersediaan loker penitipan

10. Ketersediaan papan pengumuman/infomasi

11. Ketesediaan meja-kursi baca

12. Ketersediaan fasilitas studi carrel

13. Ketersediaan meja-kursi layanan

14. Ketersediaan meja-kursi kerja staf

15. Ketersediaan meja-kursi tamu

16. Ketersediaan komputer-printer layanan

17. Ketersediaan komputer untuk pemustaka

18. Ketersediaan scanner untuk bagian pengolahan, otomasi dan layanan

19. Ketersediaan multi media (kamera, tape rekorder, DVD player, TV monitor, mikro reader dan lainnya)

20. Ketersediaan media informasi digital (TV).

Secara keseluruhan yang perlu diperhatikan dalam implementasi manajemen perpustakaan berbasi akreditasi pada aspek gedung dan sarpras dapat dirangkum dalam tabel berikut:

Menurut Pemustaka, Studi Kasus Perpustakaan Sekolah Tinggi Agama Islam. (Jakarta: Universitas Indonesia, 2009). Hlm. 79. 
Tabel 7. Kualifikasi Standar Akreditasi Aspek Gedung / Ruang dan Sarpras

\begin{tabular}{|c|c|c|c|}
\hline \multirow{2}{*}{ Aspek } & \multicolumn{3}{|c|}{ KUALIFIKASI KUALITAS } \\
\hline & CUKUP (C) & BAIK (B) & UNGGUL (A) \\
\hline Luas gedung & $\leq 499 \mathrm{~m} 2$ & $\leq 999 \mathrm{~m} 2$ & $>499 \mathrm{~m} 2$ \\
\hline Luas area koleksi & $\leq 224 \mathrm{~m} 2$ & $\leq 449 \mathrm{~m} 2$ & $>449 \mathrm{~m} 2$ \\
\hline Luas area baca & $\leq 124 \mathrm{~m} 2$ & $\leq 249 \mathrm{~m} 2$ & $>249 \mathrm{~m} 2$ \\
\hline Luas area staf & $\leq 99 \mathrm{~m} 2$ & $\leq 198 \mathrm{~m} 2$ & $>198 \mathrm{~m} 2$ \\
\hline Luas area lain & $\leq 49 \mathrm{~m} 2$ & $\leq 99 \mathrm{~m} 2$ & $>99 \mathrm{~m} 2$ \\
\hline Kebersihan & Cukup & Bersih & Sangat bersih \\
\hline Pencahayaan & Cukup & Terang & Sangat terang \\
\hline Sirkulasi udara & Cukup & Baik & Sangat baik \\
\hline $\begin{array}{l}\text { Jarak perpustakaan } \\
\text { dari pusat kegiatan }\end{array}$ & $\leq 100 \mathrm{~m}$ & $\begin{array}{c}\text { Dipusat } \\
\text { pembelajaran }\end{array}$ & $\begin{array}{c}\text { Dipusat } \\
\text { pembelajaran }+ \\
\text { Administrasi PT }\end{array}$ \\
\hline Keamanan & $\begin{array}{l}\text { Loker tanpa } \\
\text { penjaga }\end{array}$ & $\begin{array}{l}\text { Loker dengan } \\
\text { penjagaan }\end{array}$ & $\begin{array}{l}\text { Loker dengan } \\
\text { penjagaan, TV } \\
\text { monitor dan } \\
\text { CCTV } \\
\end{array}$ \\
\hline Rak buku & $\leq 15$ buah & $\leq 19$ buah & $>19$ buah \\
\hline Rak jurnal & $\leq 4$ buah & $\leq 7$ buah & $>7$ buah \\
\hline Rak surat kabar & 2 buah & 3 buah & $>3$ buah \\
\hline Rak multimedia & 2 buah & 3 buah & $>4$ buah \\
\hline Rak Referensi & 2 buah & $3 / 4$ buah & $>4$ buah \\
\hline Laci katalog & 2 buah & 3 buah & $>3$ buah \\
\hline Rak display buku baru & 2 buah & $3 / 4$ buah & $>4$ buah \\
\hline Loker & 2 buah & 3 buah & $>3$ buah \\
\hline $\begin{array}{l}\text { Lemari berkas } \\
\text { administrasi }\end{array}$ & $\leq 6$ buah & $\leq 9$ buah & $>9$ buah \\
\hline Papan pengumuman & 2 buah & 3 buah & $>3$ buah \\
\hline Study carrel & 15 buah & 20 buah & $>20$ buah \\
\hline Meja baca & $\leq 15$ buah & $\leq 21$ buah & $>21$ buah \\
\hline Meja sirkulasi & 2 buah & 3 buah & $>3$ buah \\
\hline Meja kerja staf & $\leq 10$ buah & $\leq 16$ buah & $>16$ buah \\
\hline Kursi baca & $\leq 60$ buah & $\leq 70$ buah & $>70$ buah \\
\hline Kursi tamu & 2 set & 3 set & $>3$ set \\
\hline $\begin{array}{l}\text { Komputer dan printer } \\
\text { untuk pengelolaan }\end{array}$ & $\leq 10$ buah & $\leq 16$ buah & $>16$ buah \\
\hline
\end{tabular}




\begin{tabular}{cccc}
\hline Scanner & 2 buah & 3 buah & $>3$ buah \\
\hline Komputer pemustaka & $\leq 10$ buah & $\leq 16$ buah & $>16$ buah \\
\hline Multi media & 2 buah & 3 buah & $>3$ buah \\
\hline Memsin tik & 2 buah & 3 buah & $>3$ buah \\
\hline TV & $\leq 5$ buah & $\leq 8$ buah & $>8$ buah \\
\hline Kipas angin & $\leq 5$ buah & $\leq 8$ buah & $>8$ buah \\
\hline Kamera & 2 buah & 3 buah & $>3$ buah \\
\hline AC & $\leq 5$ buah & $\leq 8$ buah & $>8$ buah
\end{tabular}

Sumber: Akreditasi Perpustakaan Perguruan Tinggi. 2011.

\section{g. Aspek Anggaran}

Anggaran adalah aspek vital keberlangsungan kegiatan penyelenggaraan perpustakaan. Dalam UU nomor 43 tahun 2007 pasal 24 (4) disebutkan bahwa setiap perguruan tinggi mengalokasikan dana untuk pengembangan perpustakaan sesuai dengan undang-undang guna memenuhi standar nasional pendidikan dan standar nasional perpustakaan. Dengan demikian, anggaran untuk perpustakaanitu harus jelas, harus terarah dan harus efektif untuk pengembangan perpustakaan. Dalam konteks ini kreatifitas dan kemampuan analisis anggaran perpustakaan untuk memenuhi kebutuhan tercapainya tujuan perpustakaan berkualitas harus kuasai oleh seorang pengelola perpustakaan.

Anggaran yang paling banyak dipakai biasanya untuk pengembangan koleksi. Selanjutnya untuk perawatan, perbaikan, kegiatan pengadaan, kegiatan kepustakawanan, pembelanjaan alat perlengkapan maupun sarana fasilitas pendukung lainnya. Ada baiknya pengelola juga melibatkan pihak luar untuk turut memberikan dukungan materiil untuk meringankan beban anggaran internal. Misalnya melalui penggalangan wakaf, hibah, sumbangan baik buku maupun dalam bentuk nilai lainnya.

Secara keseluruhan yang perlu diperhatikan dalam implementasi manajemen perpustakaan berbasi akreditasi pada aspek anggaran dapat dirangkum dalam tabel berikut: 
Tabel 8. Kualifikasi Standar Akreditasi Aspek Anggaran

\begin{tabular}{cccc}
\hline \multirow{2}{*}{ Aspek } & \multicolumn{3}{c}{ KUALIFIKASI KUALITAS } \\
\cline { 2 - 4 } & CUKUP $(\mathrm{C})$ & BAIK $(\mathrm{B})$ & UNGGUL $(\mathrm{A})$ \\
\hline Anggaran /tahun & $\leq 99$ juta & $\leq 199 \mathrm{juta}$ & $>200 \mathrm{juta}$ \\
\hline Prosentasi dari anggaran PT & $2 \%$ & $3-5 \%$ & $>5 \%$ \\
\hline Dana partisipasi masyarakat & $\leq 50$ juta & $\leq 100 \mathrm{juta}$ & $>100 \mathrm{Juta}$ \\
\hline
\end{tabular}

Sumber: Akreditasi Perpustakaan Perguruan Tinggi. 2011.

\section{h. Aspek Manajemen Perpustakaan}

Setiap organisasi memerlukan manajemen. Manajemen berfungsi untuk mengatur aktifitas seluruh elemen dalam suatu lembaga. Dalam proses manajemen diperlukan perencanaan, pengorganisasian, penganggaran, kepemimpinan dan pengendalian. ${ }^{9}$ Pernyataan ini memberikan indikasi bahwa manajemen perpustakaan itu sangat diperlukan, terkait dengan seluruh aspek kegiatan dan aktifitas organisasi.

Unsur utama dan pertama dalam sebah manajemen adalah tentang dasar pendirian organisasi, stuktur organisasi, job deskripsi, dan program-program kerja. Dari aspek tersebut kemudian melahirkan kebutuhan SDM, kualifikasiSDM, anggaran, dan evaluasi kerja yang tertuang dalam bentuk laporan. Pengelola perpustakaan harus memahami dan mampu merealisasikan manajemen organisasi semacam itu.

Beberapa permasalahan yang sering terjadi adalah, beberapa dokumen system manajemen terkadang tidak terkendali. Misalnya SK pendirian tidak dapat dilacak, struktur organsasi tidak dibuat, dibuat namun tidak disosialisasikan, deskripsi kerja staf tidak jelas, program kerja tidak didokumentasikan, tidak memiliki Standar Operasional Procedure (SOP), laporan kegiatan dan dokumentasi diabaikan dan sebagainya. Hal-hal semacam ini sudah saatnya diperbaiki demi kemajuan dan kualitas kinerja pengelolaan perpustakaan.

${ }^{9}$ Lasa HS. Manajemen Perpustakaan. Yogyakarta: Gama Media, 2005. Hlm. 1. 
Seluruhkomponenterkaitdenganimplementasimanajemen perpustakaan berbasi akreditasi pada aspek manajemen dapat dirangkum dalam tabel sebagai:

Tabel 9. Kualifikasi Standar Akreditasi Aspek Manajemen Perpustakaan

\begin{tabular}{|c|c|c|c|}
\hline \multirow{2}{*}{ Aspek } & \multicolumn{3}{|c|}{ KUALIFIKASI KUALITAS } \\
\hline & CUKUP (C) & BAIK (B) & UNGGUL (A) \\
\hline Struktur organisasi & Sederhana & $\begin{array}{c}\text { Sederhana }+ \\
\text { deskripsi tugas }\end{array}$ & $\begin{array}{c}\text { Lengkap }+ \\
\text { deskripsi tugas }\end{array}$ \\
\hline $\begin{array}{l}\text { Line of commands } \\
\text { Kepala perpustakaan }\end{array}$ & $\begin{array}{c}\text { Direktur } \\
\text { manajer non } \\
\text { akademik } \\
\text { (Kabag adm/ } \\
\text { Karo adm) }\end{array}$ & $\begin{array}{c}\text { Direktur } \\
\text { manajer } \\
\text { akademik } \\
\text { (Waket I/ } \\
\text { Warek I bidang } \\
\text { akademik) }\end{array}$ & Ketua/ Rektor \\
\hline Pendirian perpustakaan & $\begin{array}{c}\text { SK interal } \\
\text { institusi (Ketua/ } \\
\text { Rektor) }\end{array}$ & $\begin{array}{l}\text { SK Dirjen } \\
\text { Diktis }\end{array}$ & SK Menteri \\
\hline Program kerja & Jangka pendek & $\begin{array}{l}\text { Jangka pendek } \\
+ \text { menengah }\end{array}$ & $\begin{array}{l}\text { Jangka pendek, } \\
\text { menegah dan } \\
\text { panjang }\end{array}$ \\
\hline LPJ & Bulanan & $\begin{array}{l}\text { Bulanan \& } \\
\text { semesteran }\end{array}$ & $\begin{array}{l}\text { Bulanan, } \\
\text { semesteran, } \\
\text { tahunan }\end{array}$ \\
\hline
\end{tabular}

Sumber: Akreditasi Perpustakaan Perguruan Tinggi. 2011.

\section{i. Aspek Perawatan Koleksi Perpustakaan}

Telah disinggung sebelumnya tentang fasilitas sarana dan prasarana yang dibutuhkan di perpustakaan terutama untuk fasilitas koleksi serta anggaran perpustakaan untuk perawatan, perbaikan, penggantian koleksi. Dua aspek tadi terkait dengan aspek perawatan koleksi. Pengelola perpustakaan harus memahami betul tentang fungsi perpustakaan sebagai tempat penyimpanan. ${ }^{10}$ Dalam merealisasikan fungsi penyimpanan tersebut harus dipahami bagaimana penyimpanan yang baik yang bisa menjaga

${ }^{10}$ Menurut Solustiyo-Basuki dalam bukunya berjudul Pengantar Ilmu Perpustakaan; Buku Materi Pokok. (Jakarta: Universitas Terbuka, 2009) hlm. 1.9, dikatakan bahwa perpustakaan bertugas menyimpan bahan perpustakaan yang diterimanya.. 
keamanan infomasi baik secara fisik maupun isi informasi. Syarat dan kebutuhan untuk mempertahankan fungsi penyimpanan yang baik tentu membutuhkan dana. Misalnya harus membeli peralatan pendukung seperti pengatur ruangan, pengatur suhu dan pencahayaan, alat fumigasi, alat penjilidan, alat laminating, alat penggandaan dan sebagainya.

Semua kebutuhan tersebut harus masuk dalam rencana kerja dan program kerja perpustakaan serta target yang harus dicapai dalam tiap tahun kegiatan. Dan sudah menjadi tugas bagi pengelola perpustakaan untuk melakukan analisis masalah dalam perawatan koleksi serta analisis kebutuhan untuk biaya perawatannya. Karena aspek perawatan koleksi juga terkait dengan kualitas layanan yang diberikan oleh perpustakaan kepada pemustaka.

Secara menyeluruh, komponen yang perlu diperhatikan dalam implementasi manajemen perpustakaan berbasi akreditasi pada aspek perawatan koleksi dapat dirangkum dalam tabel berikut:

Tabel 10. Kualifikasi Standar Akreditasi Aspek Perawatan Koleksi

\begin{tabular}{cccc}
\hline \multirow{2}{*}{ Aspek } & \multicolumn{3}{c}{ KUALIFIKASI KUALITAS } \\
\cline { 2 - 4 } Kondisi ruang & $\begin{array}{c}\text { Menjaga } \\
\text { temperatur, } \\
\text { cahaya dan } \\
\text { kelembaban }\end{array}$ & $\begin{array}{c}\text { Temperatur } \\
\text { dan cahaya } \\
\text { ideal }\end{array}$ & $\begin{array}{c}\text { Memperatur, } \\
\text { cahaya dan } \\
\text { kelembaban } \\
\text { ideal }\end{array}$ \\
\hline Fumigasi dan insektisida & 3 tahunan & 2 tahunan & 1 tahunan \\
\hline $\begin{array}{c}\text { Jumlah perbaikan bahan } \\
\text { perpustakaan/tahun }\end{array}$ & $\leq 100$ eksemplar & $\begin{array}{c}\text { Und } \\
\text { eksemplar }\end{array}$ & $>150$ eksemplar \\
\hline
\end{tabular}

Sumber: Akreditasi Perpustakaan Perguruan Tinggi. 2011.

\section{SIMPULAN}

Standar acuan artinya ukuran minimal yang harus dijadikan acuan dalam penyelenggaraan perpustakaan berdasarkan pedoman yang berlaku dan disepakati bersama. 
Dalam hal ini menggunakan salah satu pedoman standar yaitu standar nasional perpustakaan.

Ada sembilan aspek yang menjadi sorotan dan harus diperhatikan dalam rangka mencapai tujuan dan target pencapaian kualitas perpustakaan. Mulai dari layanan, kerjasama, koleksi, bahan perpustakaan, sdm perpustakaan, gedung dan sarana prasarana, anggaran, manajemen, dan perawatan koleksi. Tiap aspek memiliki kualifikasi yang menjadi patokan atau ukuran standar tertentu.

Dengan memahami kesembilan aspek akreditasi ini diharapkan setiap pengelola perpustakaan akan lebih terarah dalam pengelolaan perpustakaan. Karena sudah ada acuan yang dijadikan sebagai roadmap pengelolaan perpustakaan untuk masa yang akan datang. Inilah maksud dari pengelolaan perpustakaan berbasis akreditasi sebagaimana harapan penulis, dalam rangka mencapai tujuan utama yaitu terwujudnya perpustakaan yang berkualitas. 


\section{DAFTAR PUSTAKA}

Badan Standardisasi Nasional. Sistem Manajemen MutuPersyaratan. Quality Management Systems-Requirement (ISO 9001, IDT). Jakarta: BSN, 2008.

Hanief Saha Ghafur. Manajemen Penjaminan Mutu Perguruan Tinggi di Indonesia, Suatu Analisis Kebijakan. Jakarta: Bumi Aksara, 2010.

Ikhwan. Pentingnya Perpustakaan di Perguruan Tinggi. Makalah diakses melalui http://perpustakaan.unrama.ac.id tanggal 12 September 2016.

Komarudin. (2015). Akreditasi Perpustakaan Perguruan Tinggi: Pengalaman Perpustakaan STAIN Kediri. Jurnal Pustakaloka. Volume 8 nomor 1 (2016).

Lasa HS. Manajemen Perpustakaan. Yogyakarta: Gama Media, 2005.

Nurohman, Aris. Gedung Perpustakaan: Fungsi dan Simbolismenya Menurut Pemustaka, Studi Kasus Perpustakaan Sekolah Tinggi Agama Islam. Jakarta: Universitas Indonesia, 2009

O'brien, Karen L.. Accreditation of Library and Information Science Education. Encyclopedia of Library and Information Science, Third Ed. 1, 2010.

Prabowo, Sugeng Listyo. Implementasi Sistem Manajemen Mutu ISO 9001:2008. Malang: UIN Press, 2009.

Priyanto, da F. Priyanto. Perpustakaan Akademik Dalam Bingkai Perguruan Tinggi Berkualitas. Makalah. Diakses melalui www.digilib.ugm.ac.id tanggal 10 Februari 2015.

Republik Indonesia. Undang-Undang Nomor 43 tahun 2007 tentang Perpustakaan. Jakarta: Perpustakaan Nasional, 2007.

Subagio, Adwityani S. Persiapan Akreditasi Bidang Perpustakaan di Perguruan Tinggi. Makalah disampaikan pada workshop nasional Persiapan Akreditasi bidang Perpustakaan di Perguruan Tinggi di Jakarta tanggal 12 Juli 2012. 
Sulistiyo-Basuki. Pengantar Ilmu Perpustakaan; Buku Materi Pokok. Jakarta: Universitas Terbuka, 2009.

Suparmo, Paulus. Mengagas Kualitas Perpustakaan Perguruan Tinggi. Makalah disampaikan pada woskhop Akreditasi Perpustakaan di STAIN Purwokerto. Purwokerto,13 Oktober 2012.

Tim Penyusun. Standar Nasional Perpustakaan Perpustakaan Perguruan Tinggi SNP 010:2011. Jakarta: PNRI, 2011.

Tim Penyusun. 2007. Kamus Besar Bahasa Indonesia. Jakarta: Balai Pustaka 
Halaman ini bukan sengaja untuk dikosongkan 